\title{
Review on additive hybrid- and multi-material-manufacturing of metals by powder bed fusion: state of technology and development potential
}

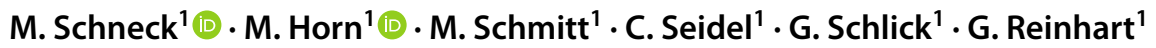

Received: 18 November 2020 / Accepted: 19 June 2021 / Published online: 7 August 2021

(C) The Author(s) 2021

\begin{abstract}
In this review paper, the authors investigate the state of technology for hybrid- and multi-material (MM) manufacturing of metals utilizing additive manufacturing, in particular powder bed fusion processes. The study consists of three parts, covering the material combinations, the MM deposition devices, and the implications in the process chain. The material analysis is clustered into 2D- and 3D-MM approaches. Based on the reviewed literature, the most utilized material combination is steel-copper, followed by fusing dissimilar steels. Second, the MM deposition devices are categorized into holohedral, nozzle-based as well as masked deposition concepts, and compared in terms of powder deposition rate, resolution, and manufacturing readiness level (MRL). As a third aspect, the implications in the process chain are investigated. Therefore, the design of MM parts and the data preparation for the production process are analyzed. Moreover, aspects for the reuse of powder and finalization of MM parts are discussed. Considering the design of MM parts, there are theoretical approaches, but specific parameter studies or use cases are not present in the literature. Principles for powder separation are identified for exemplary material combinations, but results for further finalization steps of MM parts have not been found. In conclusion, 3D-MM manufacturing has a MRL of 4-5, which indicates that the technology can be produced in a laboratory environment. According to this maturity, several aspects for serial MM parts need to be developed, but the potential of the technology has been demonstrated. Thus, the next important step is to identify lead applications, which benefit from MM manufacturing and hence foster the industrialization of these processes.
\end{abstract}

Keywords Additive manufacturing $\cdot$ Functionally graded materials $\cdot$ Hybrid manufacturing $\cdot$ Multi-material

\section{Introduction and motivation}

Functionally graded materials (FGMs) are characterized by a variation of material properties over the dimensions of a part $[1,2]$. This allows tailoring material properties within a part corresponding to the local material requirements. Thus, FGMs enable advanced opportunities to optimize products and foster innovations. The production of FGMs can be realized by several manufacturing processes, which are investigated by El-Galy et al. [3], but additive manufacturing (AM) is especially suitable for producing FGMs [1].

M. Schneck

matthias.schneck@igcv.fraunhofer.de

1 Fraunhofer Institute for Casting, Composite and Processing Technology IGCV, Augsburg, Germany
In general, additive manufacturing is considered an important technology trend in production industry [4]. This has been demonstrated by a strong market growth in AM over the last years, for processing of metals especially since 2012 onwards [5]. The additive manufacturing technologies are split into seven process classes, defined in ISO/ASTM 52900 [6]. The most important process class in metal-based $\mathrm{AM}$ is powder bed fusion (PBF) and within this class, the process of laser-based powder bed fusion [7] (PBF-LB) [6]. Furthermore, the process of electron beam melting (PBFEB) [6] belongs to this process class. Following Popov et al. [8], the production of FGM is "is one of the modern unique options provided by the PBF-systems". Moreover, following Schleifenbaum et al. [4], one of the current limitations of the PBF-LB process is the lack of AM-tailored materials and multi-material processing.

The benefits of FGMs, which are especially graded materials or hybrid materials, are frequently discussed in the 
context of AM [1, 3, 8-12]. This paper reviews the current state of hybrid- and multi-material- manufacturing (MM) for PBF processes and summarizes the state of technology in this field. This includes the current limitations, technology potential, and development perspective.

\section{Definitions}

A multi-material part in the context of this review consists of an FGM with a discrete or graded material transition. Several AM processes allow the manufacturing of material combinations and FGMs. The investigation of this paper is focused on metal-based PBF processes, which is set into the context of the seven functional AM principles in Fig. 1. More general literature overviews, which also take other metal-based AM principles into consideration are given by Reichardt et al. [7], Zhang et al. [12], Wei et al. [11] as well as Bandyopadhyay and Heer [13].

The ability of AM to produce FGMs is defined in ISO/ ASTM TR 52912 [14] as "a layer-by-layer fabrication technique that intentionally modify process parameters and gradationally varies the spatial of material(s) organization within one component to meet intended function." For FGMs produced by AM, the abbreviation FGAM is introduced [14].

A holistic definition of multi-material in the context of AM has been proposed by Girnth et al. [15], which is concretized by Koopmann [16]. In this definition, MM is categorized depending on the geometrical dimensions in which the material is graded. Moreover, the number of different materials is considered, whereby two materials are named as hybrid-material and three or more materials within one part as multi-material.

Another definition is stated by Vaezi et al. [17], differentiating by the layer-wise PBF build process in "material change between layers," "material change within layers," and "material change between and within layers." Further

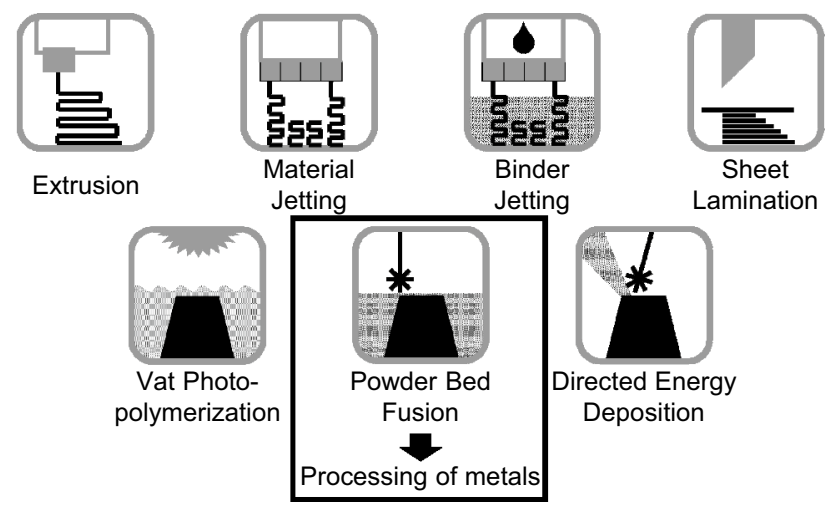

Fig. 1 Focus of the review in the context of AM principles definitions, which incorporate the prior perspectives are stated in $[18,19]$. The type of material transition can be discrete or graded [20, 21].

Considering these references, there are two perspectives to define MM parts: the first logic is based on the PBF machine coordinate system and the other one uses the material gradient within the part structure.

The coordinate system for AM systems is defined in ISO/ASTM 52921 [22]. The layer-based perspective corresponds to this definition, describing the material transition between layers as 2D structure with a material change along the $\mathrm{z}$-axis and the transition of material within and between layers as 3D structure. The definition is depicted in Fig. 2.

In this paper, the MM structures are categorized by geometrical dimension into 2D structures, which cover material transitions in one dimension and 3D structures, which cover material transitions in at least two dimensions.

Besides the combination of two materials, the term hybrid additive manufacturing is also used to describe the combination of different manufacturing processes [23, 24]. Therefore, in this study, a 2D material transition, in which Material A is a conventionally manufactured material and Material B is additively built on top of Material A, is named as hybrid additive manufacturing approach. A conventionally manufactured material is mainly produced by subtractive or formative technologies as defined in ISO/ASTM 52900 [14].

As one criterion to assess the maturity of the investigated MM approaches, the concept of manufacturing readiness level (MRL) [25] is used which is closely linked to the technology readiness level (TRL) [26]. The MRL scale covers ten levels, starting from identified manufacturing implications (MRL 1) to full rate serial production (MRL 10) [25].

\section{Research approach}

The literature review presented in this paper is based on two leading statements, which are derived from the research objective. The first leading question clarifies if a literature source describes a multi-material approach under the scope of this review:

"A metallic material is processed utilizing a PBF principle in combination with another material"

The second lead statement identifies specialized systems and devices, which are proposed to manufacture MM parts:

"A specialized material delivery system is described for the manufacturing of MM parts"

The literature identified by these leading questions was collected and structured. For the structuring the prior definitions applied, but were differentiated by additional 
Fig. 2 Definition of 2D and 3D multi-material structures

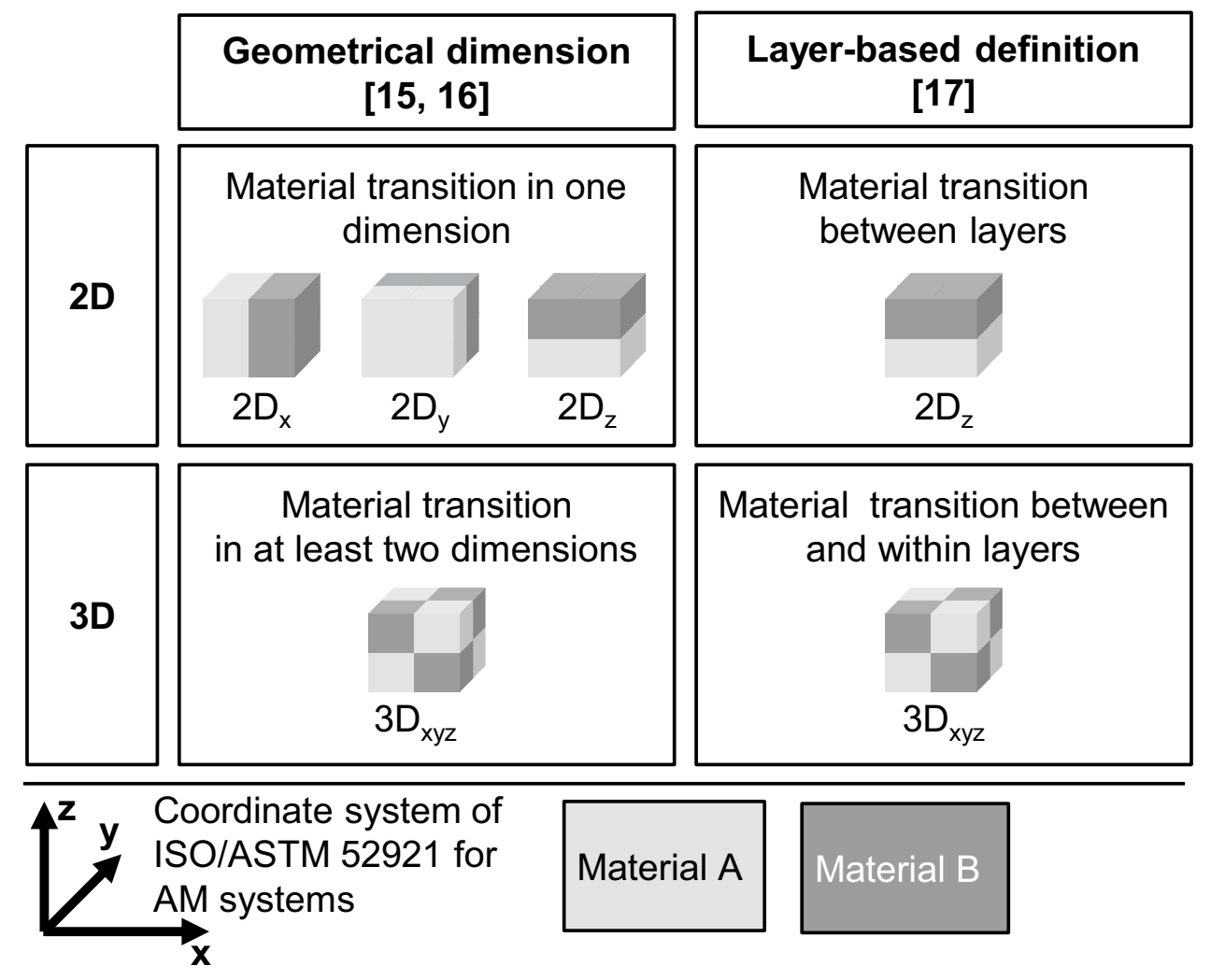

subcategories. The findings are analyzed in three perspectives. First the material combinations are derived and compared. Moreover, the functional principles of systems for the production of MM parts are investigated. As a third aspect, the implications of MM for the AM process chain are concluded, considering the pre-, in- and post-process. Lastly an overall summary of the state of technology for MM parts is concluded and discussed.

\section{Hybrid- and multi-materials overview}

In this section, the material combinations of 2D- and 3D$\mathrm{MM}$ are investigated. For each source, the specific PBF process, MM deposition approach, and material combination is stated. For each material, the base alloy component is stated, and in addition the precise definition of the material, if stated by the author.

In general, the material transition consists of four different zones, which were investigated by Link et al. [27] for 2D hybrid manufacturing. The four zones are depicted in Fig. 3.

The first zone is Material A, which is produced by another manufacturing process for the case of hybrid manufacturing or with the corresponding AM process parameters to process Material A. The following heat affected zone occurs in hybrid manufacturing and when there is a change in the production parameters within the AM process, especially if

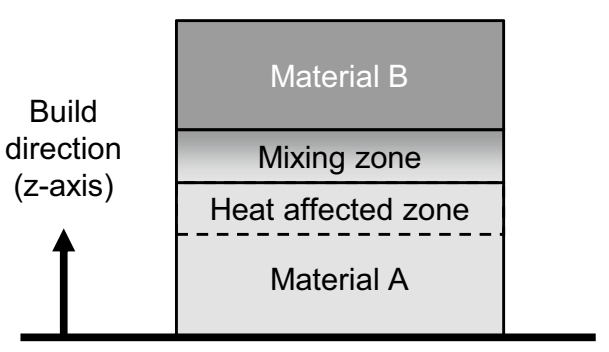

Fig. 3 Material transition zones (based on [27])

the deposited energy per volume unit increases significantly. The heat affected zone forms as a result of the AM process parameter change in the mixing zone. The mixing zone is characterized by the mixing up of Material A and B in the microstructure and the transition of process parameters. Lastly, the fourth zone is pure Material B with corresponding process parameters. In the investigation of Link et al., the heat affected zone and the mixing zone are approximately $150 \mu \mathrm{m}$ each [27].

For a 3D-MM approach, the material transition zone has the shape of a freeform surface. Thus, the angle between the direction of material transition and the build direction (z-axis) is not constant, which requires a joining strategy adapting to the local requirements. This joining strategy must at least consider the adaption of process parameters, 
order of exposure, and geometrical overlap of material zones [28].

\subsection{D-multi-material}

2D-MM approaches are described by 33 literature sources. These approaches split into 17 hybrid manufacturing approaches, which cover building of additively manufactured material on top of a conventional manufactured one, and 16 fully additive approaches, investigating the bonding between two AM materials. Appendix Table 3 (see Appendix) provides an overview of the literature sources for $2 \mathrm{D}-\mathrm{MM}$ approaches. For the 2D hybrid manufacturing approaches, the base material is listed as Material A. The references in Appendix Table 3 are sorted by descending publication date.

Almost all sources utilize the PBF-LB process for the 2D multi-material approach. Only Jurisch et al. [29] state a hybrid manufacturing process for electron beam melting (PBF-EB) and Regenfuss et al. for a micro PBF-LB process [30]. Moreover, in all references the material transition is along the building direction (z-axis, $2 \mathrm{Dz} M \mathrm{MM}$ ), except for Beal et al. [31], proposing a coater system with chambers to vary the material over the deposition coater axis (y-axis, 2 Dy MM). This approach allows varying the material in one dimension, but has no material change between layers.

\subsection{D-multi-material}

3D multi-materials (3D-MMs) are described by 17 literature sources. Based on the maturity of the MM process, the literature sources are categorized into three levels of maturity. The first level is the proposal of a theoretical concept without proofing the functionality in a prototype or demonstrator. These literature sources cover only theoretical approaches to manufacture MM parts. On the second maturity level, the references demonstrate the deposition of a MM layer, but without the solidification by an AM process. On the third maturity level, the manufacturing of a MM part is presented, demonstrating the functionality of the proposed 3D-MM manufacturing system.

Appendix Table 4 (see Appendix) lists the literature references for 3D-MM. Fourteen references demonstrate the building of a 3D-MM part by a PBF process. Moreover, two references present deposition systems to prepare a MM layer without integrating it into an AM system or building a 3D-MM part [32, 33], whereas Gerstgrasser et al. state a theoretical concept of a nozzle deposition system [34].

To manufacture a 3D-MM part, specialized machine equipment is required to generate a MM layer of metal powder, which can be realized by three different deposition concepts: holohedral concepts, which coat the whole powder bed; nozzle-based concepts, which deposit powder through a nozzle or nozzle array and masked concepts, which allow to selectively apply different powders. The deposition concepts to manufacture 3D MM parts are discussed in detail in Sect. 5.

\subsection{Material combinations}

The analysis of material combinations shows that there is a strong focus on steels as one part of the material combination, (see Table 1). The most investigated material transition is between steel and copper, which is stated in 21 references. The second most utilized material combination, stated in ten references, is to bond steels together. Whereas the focus for the steel-copper combination is in 3D-MM, the bonding of two steels is mainly investigated in 2D hybrid manufacturing. Further material combinations, which are investigated by 2-5 references, focus on three aspects: the bonding of aluminum alloys to other metals, the bonding of steel and Ni-base alloys, and the bonding of steel and ceramics. The bonding of aluminum alloys is investigated as the combination of aluminum alloy to aluminum alloy within a $2 \mathrm{D}$ hybrid approach, aluminum alloy to copper, and aluminum alloy to steel.

Considering the MM approaches, 2D hybrid manufacturing is mainly utilized to join similar metals, e.g., two steels or two aluminum alloys. A material combination of metal and non-metal utilizing a 2D hybrid manufacturing approach was not identified in the review. When both materials are made additively with a 2D-MM approach, the bonding of steels and aluminum alloys to other materials is investigated. In contrast, the 3D-MM approach has a strong focus on steel-copper combinations (13 references), followed by the bonding of metals and non-metals ( 6 references).

In general, it is remarkable that some common materials for PBF-LB were not identified in the review of MM approaches. Especially, titanium and titanium alloys were

Table 1 Overview of MM material combinations

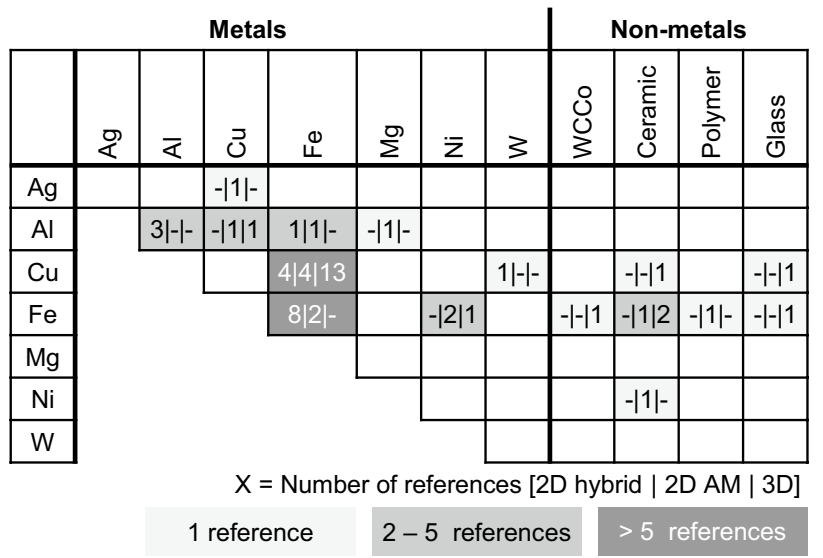


not identified for MM manufacturing, despite the fact that they are often utilized in the medical and aerospace sector.

\section{Deposition devices for 3D-multi-material}

For the application of two different powder materials to manufacture 3D-MM parts, extended powder deposition techniques are required. Neirinck et al. give an overview and detailed descriptions of existing technical concepts [35]. Comparing all concepts, three generally different overarching approaches can identified: holohedral deposition concepts, nozzle-based concepts, and masked deposition concepts. To compare the three types and evaluate their potential, solutions presented in the literature are described and assessed in terms of powder deposition rate, deposition resolution in terms of minimal feature sizes, and manufacturing readiness level (MRL). First, the deposition rate is considered as an estimator for the amount of powder that can be deposited during a certain amount of time. The monomaterial coating process can serve as a benchmark. Second, the resolution of the processes is assessed to estimate the minimum size of powder features as well as solidified part features, which have been created in past studies. Third, the MRL in accordance with the definition by the Department of Defense (DoD) is assessed [25]. Figure 4 summarizes the results of the comparison, which is discussed in detail in the following section.

\subsection{Holohedral deposition concepts}

Holohedral coating mechanisms spread respective materials evenly across the entire build plate. MM capabilities are achieved by separation of powder storage and delivery chambers within the coater. Although not applied for MM

\begin{tabular}{llll}
\hline & $\begin{array}{l}\text { Holohedral } \\
{[19,28,} \\
37,38,50]\end{array}$ & $\begin{array}{l}\text { Nozzle-based } \\
{[15,16,33,35,} \\
52,53]\end{array}$ & $\begin{array}{l}\text { Masked } \\
{[32,55,56]}\end{array}$ \\
\hline $\begin{array}{l}\text { Coating rate } \\
\text { in } \mathrm{mm}^{3} / \mathrm{s}\end{array}$ & $40-140$ & $0.4-4.1$ & $130-290$ \\
\hline $\begin{array}{l}\text { Powder } \\
\text { resolution in } \\
\text { x/y/z mm }\end{array}$ & - & $0.09-1.3 /$ & $0.8-1.6 /$ \\
\hline $\begin{array}{l}\text { Part } \\
\text { resolution in } \\
\text { x/y/z mm }{ }^{3}\end{array}$ & $<1 / 1 / 1$ & $0.09-1.3 /$ & $0.8-1.6 /$ \\
& & $0.1-0.15$ & unknown \\
\hline
\end{tabular}

Fig. 4 Comparison of 3D-MM powder deposition concepts parts and thus not considered for further evaluation, 3D-MM capabilities can be enabled by separation of the coater's powder chambers parallel to the powder coating direction [31] combined with a hybrid manufacturing approach (see Sect. 4.1). Anstaett and Anstaett et al. presented a solution with separation of the powder chambers perpendicular to the coating direction [19, 28, 36-38]. 3D-MM capability is achieved by a suction unit, which removes unsolidified powder material after exposure of the respective layer with the laser. Without lowering the build plate, the second powder material can be applied to the same layer. After solidifying the second material, the build plate is lowered and the process is repeated.

This concept requires a minimum of four travels of the coater per layer: first cycle deposition Material A, second cycle suction of loose powder Material A, third cycle deposition of Material B, fourth cycle suction of loose powder Material B. Given a coating time of $7 \mathrm{~s}$ for mono-material processes in mid-size PBF-LB systems [39, 40], effective layer heights of 75-110 $\mu \mathrm{m}$ [41], and powder densities of $40 \%$ [42] to 56\% [43], the system presented by Anstaett and Anstaett et al. [19, 28, 36-38] has an estimated deposition rate of $60-140 \mathrm{~mm}^{3} / \mathrm{s}$, compared to $240-560 \mathrm{~mm}^{3} / \mathrm{s}$ for mono-material PBF-LB. The minimum feature size is determined by the laser and is thus comparable to monomaterial parts, being 130-240 $\mu \mathrm{m}$ [44], plus nominal overlaps of 100-200 $\mu \mathrm{m}$ at a layer height of $30 \mu \mathrm{m}$ for, e.g., the transition zone of tool steel 1.2709 and copper alloy CW106C [38, 45]. Part features of copper alloy CW106C considerably smaller than $1 \times 1 \times 1 \mathrm{~mm}^{3}$ have already been demonstrated in tool steel 1.2709 parts [46]. Due to the fact that technology demonstrators have been manufactured in a laboratory environment [46], holohedral deposition concepts are considered to have a MRL between 4 and 5 .

\subsection{Nozzle-based deposition concepts}

Nozzle-based deposition concepts for MM PBF date back to the early 1990s [47]. The majority of systems rely on interparticular forces, which prevent powders from flowing freely through a nozzle's orifice. Actuators fluidize the powders for defined deposition while moving the nozzle over the powder bed or the previously solidified part to create single powder lines. Work conducted by Kordaß et al., where metal powder filled pastes are extruded by nozzles, is the only exception [48, 49]. Generally, 3D MM capabilities are achieved by combining two [15, 16, 50], three [33], or entire arrays [34, 51] of nozzles depositing different materials. Alternatively, one or more nozzles can be combined with a holohedral powder coater to deposit the second or third material, respectively [18, 52]. Sometimes, an additional suction nozzle is used to locally remove unsolidified excess material from the powder bed before a different material 
is applied [15, 52]. Girnth et al. summarized six different approaches to apply and - if necessary-remove two different powder materials using nozzle-based powder dispensers, a holohedral coater, and a suction unit [15].

Depending on the deposition method, process times can vary [15]. For comparison of the deposition concepts, the deposition rate of a single nozzle is considered. A nozzle travel speed of $5-15 \mathrm{~mm} / \mathrm{s}$, led to deposition rates of 10 and $30 \mathrm{mg} / \mathrm{s}$ for copper and $\mathrm{SnPb}$, respectively [33]. Zhang et al. achieved deposition rates of up to $32 \mathrm{mg} / \mathrm{s}$ for stainless steel 316L [50], whereas Al-Jamal et al. measured feed rates of $10-13 \mathrm{mg} / \mathrm{s}$ for copper and H13 steel [53]. Koopmann achieved feed rates of $64.2,48.3,22.3$, and $19.7 \mathrm{mg} / \mathrm{s}$ for copper, a copper alloy, steel 1.2367 as well as a mixture of $\mathrm{A} 12 \mathrm{O} 3$ and $\mathrm{ZrO} 2$ powder, respectively [16]. Considering the respective materials' densities and again assuming powder densities of 40 [42] to 56\% [43], across all previously mentioned sources deposition rates between 0.4 and $4.1 \mathrm{~mm} 3 / \mathrm{s}$ per powder nozzle are estimated. Minimum feature sizes have to be divided into powder feature sizes and part feature sizes. Regarding the former, powder feature sizes in the range of $85 \mu \mathrm{m}$ [33], $555 \mu \mathrm{m}$ [50], and $1.3 \mathrm{~mm}$ [15] for track heights of $100 \mu \mathrm{m}$ [15] to $150 \mu \mathrm{m}$ [50] were achieved. Regarding the latter, Wei et al. printed part features with a nominal layer height of $50 \mu \mathrm{m}$ and horizontal cross-sections of $1 \mathrm{~mm}$ as well as lattice structures with a strut thickness of $150 \mu \mathrm{m}$ [52]. Koopmann created irregular circuit paths with a width of $2 \mathrm{~mm}$ and a height of $0.2 \mathrm{~mm}$, which contained build defects [16]. In terms of MRL, nozzle-based deposition concepts vary between the levels 4 and 5 .

\subsection{Masked deposition concepts}

Masked deposition concepts are able to deposit complex shapes of at least two different powder materials with a single travel of the powder coating mechanism by masking defined areas for powder pick-up and/or deposition. Currently, two different masking mechanisms have been identified. First, photo-masking and electrostatic attraction can be used to pick up defined powder patterns and deposit them accordingly [32]. This principle is referred to as photoconductor and can be compared to the basic xerography principle transferred to fine metal powders. The second masking mechanism utilizes a pressure-based principle. Due to a gas flux and resulting negative pressure inside a cylindrical drum consisting of fine meshes with diameters smaller than the finest particle to be processed, the pressure-based module suctions thin powder layers onto the outer surface of the sieve drums. A matrix of valves can locally offset the negative pressure and thus deposit the powder from the sieve drum onto a substrate plate [54]. Two rotating drums combined in a single coater enable deposition of 3D-MM powder layers [54, 55].

The photoconductor principle has been used to deposit MM powder layers in a laboratory environment outside a PBF machine [32] and was found to have potential for 3D-MM PBF-LB [36]. Due to a MRL of 2 and the early development stage, powder deposition rates are not available. Powder features with about $1 \mathrm{~mm}$ in diameter have been created, but minimum feature size has not yet been studied [32].

Based on a demonstration video of the company which markets the solution, a 3D-MM powder layer with a length of $150 \mathrm{~mm}$ was created by the pressure-based module in about $8 \mathrm{~s}$ [56]. Transferring the deposition speed to a midsize PBF-LB machine with a build plate of $250 \times 250 \mathrm{~mm}^{2}$ and assuming the powder layer has the same thickness and density of conventional coating systems (see Sect. 5.1 for comparison) leads to an estimated powder deposition rate of $130-290 \mathrm{~mm}^{3} / \mathrm{s}$. Based on published images of created powder layers, single line widths of deposited powder features are $0.8-1.6 \mathrm{~mm}$ [55]. Although the system has been implemented in a PBF-LB system and a part has been created [57], minimum feature sizes of solidified materials have not yet been studied. The maturity of the pressure-based system is considered at a MRL level of 3-4.

\section{Implications of multi-material manufacturing in the additive process chain}

A generalized AM process chain is defined in VDI 3405 [58], consisting of pre-process, which are all process steps before an AM manufacturing process can be executed, the in-process, which covers all steps performed at the AM system, and the post-process, which includes all required process steps to obtain the technical functionality of the AM part. In the following sections, the implications of MM for the pre-, in- and post-process are discussed.

\subsection{Pre-process: design and data preparation}

The discussion of the pre-processing is split into two parts. At first, the general implications to develop a design for a MM part are investigated. These design approaches are not limited to a specific MM process. Second, the preparation of the manufacturing task and setting of suitable process parameters for the MM system (build job) is presented in detail.

The design of MM parts is investigated in the context of general design approaches for AM. A MM design is seen 
as an opportunity, which is enabled by AM manufacturing processes $[9,59]$, but also bears additional complexities through the combination of the materials [60]. The challenges occur from the definition of an ideal material distribution, the prediction of material properties, appropriate material selection, the definition of material properties on a local level, and software limitations [20]. In general, established design processes of parts and the supporting software (e.g., computer aided design, CAD; finite element analysis, FEA) are based on a geometrical representation with monolithic material properties. To develop MM parts, this approach must be overcome, allowing to model material properties on a local level within the part [61]. Furthermore, a MM design process demands starting with the intended material properties instead of a geometrical representation [61, 62]. An approach to represent material gradients in a volumetric model, based on subdivision schemes, is proposed in Altenhofen et al. [63]. In addition, a topology optimization approach, considering multi-materials is described in Zou and Saitou [64].

After developing a MM design, it must be prepared for the manufacturing process in the MM system. For that, a geometrical representation of the MM part, including the material gradients is required. Moreover, the process parameters for the AM process must be assigned.

In the current data preparation process for a coater-based MM concept, each volumetric section with specific process parameters is represented by a separate STL file, which describes the surface of the volume section $[52,65,66]$. A nozzle concept requires a separate $\mathrm{CNC}$ code to operate the nozzle kinematic, which is derived from the origin geometry [15].This process is considered to be complicated and thus prone to errors in the data preparation [19]. Due to the representation as STL files, the process is not capable of manufacturing gradient material transitions. Moreover, process parameter must be adapted to the local geometry of the material transition area [16].

A data format that supports gradient materials within the represented volume enables a more efficient data preparation process $[19,65]$. An overview of such data formats (e.g., AMF, 3MF, FAV, SVX) is provided in Loh et al. [61], but several state-of-the-art AM systems do not implement them [65]. Additionally, a first approach based on machine learning algorithms to predict suitable scanning parameters for the gradient materials and the mixing zone is presented by Rankouhi et al. [67].

\subsection{In-process}

Aspects for the in-process are mainly caused by the AM and powder deposition systems, which are discussed in Sect. 5 .
Additional aspects, however, include strategies for processing multiple materials and understanding of metallurgical processes in the mixing and heat affected zones as well as process monitoring solutions.

Models for the simulation of metallurgical process of multi-material PBF and in situ alloying as well as respective validations are presented by Küng et al. [68], Wei et al. [66] and $\mathrm{Gu}$ et al. [69]. Haokun et al. investigated the transition zone of $\mathrm{Al}, \mathrm{Cu}$ and $\mathrm{Al}-\mathrm{Cu}$-powder mixtures on stainless steel substrate and derived melt pool simulations for the material combinations [70]. More generally, Reichardt et al. gathered alloy compatibilities and predominately occurring defects for relevant material combinations in metal-based MM AM [7]. A general review of metallurgical aspects and overall process implications is provided by Sing et al. [71].

In terms of process monitoring, bonding of layers of different materials as well as powder deposition inaccuracies and cross-contaminations need to be considered. Binder et al. used active thermography for multi-material powder layer monitoring. Initial tests enabled detection of copper alloy CW106C contamination in tool steel 1.2709 and vice versa [65]. Kleszczynski et al. observed foreign particles during the process with a charge-coupled device (CCD) camera [72]. Furthermore, Jamshidinia et al. were able to detect agglomerates and single particles of tungsten during the in-process of Inconel ${ }^{\circledR} 625$ using a spectrometer, a photodetector, and an optical camera, with the photodetector being the most promising [73].

\subsection{Post-process: powder separation and part finalization}

Post-processing includes the finalization of MM parts to meet technical specifications [58] and often consists of thermal treatments, pressing, and surface modifications. These processes need to be adjusted for MM parts [65]. Yet no publication was found to address the post-processing of MM parts created by PBF. Yang and Zhao, however, suggested that MM parts cannot be fully recycled [9].

The post-process also includes the reconditioning of unsolidified powder material, since cross-contaminations cannot be fully avoided during the MM PBF in-process. Because remaining foreign particles can lead to inferior material properties, the powder materials need to be sorted before their reuse [74]. Contamination levels arising during the in-process depend on the facilitated deposition device and have not been studied for every concept. For the holohedral deposition concept presented by Anstaett [19], contamination levels vary between 14 and 40 weight percent (wt.\%) in the rear powder overflow as well as the front powder overflow and suction unit, respectively [65]. For their suggested 
powder deposition methods, Girnth et al. concluded that increased MM powder deposition rates lead to increased levels of powder cross-contaminations [15].

Due the particle size, the requirements in terms of powder quality, and the physical similarity of processed powder materials existing recycling methods from other industries are only partially applicable to MM PBF powder mixtures. Therefore, Horn et al. conducted a utility value analysis and identified nine process groups relevant for PBF powders [75]. Among the most promising ones are sieving and ferromagnetic separation, which have previously been suggested by Chivel [76] and Sing et al. [77] as well as Sing et al. [77], respectively. Powder separation based on ferromagnetic properties of one component can either be conducted manually [19, 75] or automated [78]. However, for manual separation, the non-ferromagnetic component yielded purities above $99 \mathrm{wt} . \%$, whereas the ferromagnetic powder material remained below $80 \mathrm{wt} . \%$ purity [75]. Automated sorting trials were below these purity levels [78]. Processing powder materials with different particle size distributions over three 3D-MM PBF-LB process cycles and sorting them via sieving yielded powder purities above 97.6 particle percent (part.\%) and good powder recovery rates. Furthermore, Horn et al. investigated the applicability of sedimentation processes and found tungsten to be separable from aluminum and titanium alloys [79]. If applied to non-corrosive fluids, the powders are also not expected to pick up oxygen,

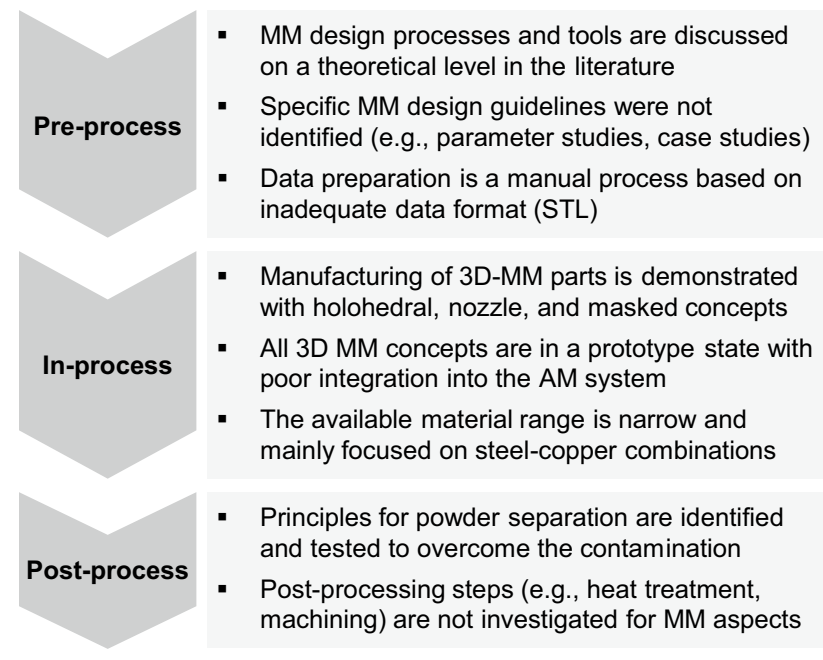

Fig. 5 Development state of multi-material processes nitrogen, or hydrogen during wet dispersion separation processes [79].

\section{Conclusion and outlook}

The vision for multi-material (MM) manufacturing through AM is to produce parts that utilize different materials specified by local requirements, which means to produce FGMs with a discrete or graded material transition. In this review, the focus is set on metal MM manufacturing by powder bed fusion (PBF) processes. The current state of research is summarized in Fig. 5, following the process steps of the generalized AM process chain.

Considering the technological aspects in the pre-processing, the design of MM parts is just in the beginning stages. First publications discuss processes and tools on a theoretical level, but specific results, like parameter studies or use cases are not available. Moreover, the data preparation for the AM process is based on STL files, which represent only geometrical information. Thus, the current preparation process is manual and error-prone. In the context of MM especially, the benefits of advanced data formats for AM are discussed, which allow defining material properties within the part geometry. If these data formats become a new standard in the AM sector, the modeling and representation of MM parts is facilitated.

In the in-process, the manufacturing of 3D-MM parts is demonstrated with holohedral, nozzle-based, and pressurebased masked deposition devices. MM powder deposition

Table 2 Maturity level of multi-material in PBF

\begin{tabular}{|c|c|c|c|c|c|c|c|c|c|c|}
\hline & \multicolumn{10}{|c|}{ Manufacturing readiness level MRL } \\
\hline & 1 & 2 & 3 & 4 & 5 & 6 & 7 & 8 & 9 & 10 \\
\hline \multicolumn{11}{|l|}{ Reference } \\
\hline PBF-LB & & & & & & & & & & \\
\hline PBF-EB & & & & & & & & & & \\
\hline \multicolumn{11}{|l|}{ 2D Multi-Material } \\
\hline 2D hybrid & & & & & & & & & & \\
\hline 2D full $A M$ & & & & & & & & & & \\
\hline \multicolumn{11}{|l|}{ 3D Multi-Material } \\
\hline Holohedral & & & & & & & & & & \\
\hline Nozzle & & & & & & & & & & \\
\hline $\begin{array}{l}\text { Masked } \\
\text { (Pressure-based) }\end{array}$ & & & & & & & & & & \\
\hline $\begin{array}{l}\text { Masked } \\
\text { (Photoconductor) }\end{array}$ & & & & & & & & & & \\
\hline
\end{tabular}


performance varies between deposition strategies. While masked deposition devices have the lowest MRL, their deposition rate is comparable to the lower end of mono-material processes. If powder deposition resolution is increased, these technologies show large potential. Nozzle-based solutions have a higher MRL, yet deposition rates are roughly a hundred times lower than masked and holohedral devices. Low levels of cross-contaminations and minimum material requirements, however, make nozzle-based systems relevant for the creation of thin layers or small features, like circuit paths or the processing of expensive materials. Holohedral deposition concepts currently have a high MRL, high resolution, and a high deposition rate. The latter could also be increased by, e.g., combining the suction with the deposition step. But their major drawback is the high level of cross-contaminations. All in all, currently only prototype AM systems in a research environment are capable of manufacturing MM parts. These systems are utilized as a proof-of-concept, but do not allow the manufacture of MM parts with the reliability required for production. For the $2 \mathrm{D}$ hybrid manufacturing approach, serial applications are proposed by manufacturing companies [80]. The available material range in MM is limited. The most investigated material combinations are steelcopper and steel-steel. To proceed in the development of MM manufacturing a reliable AM system, capable of MM, is required. Moreover, the material range can be extended by integrating results from related technology fields \{e.g., welding of dissimilar materials $[81,82]\}$. In terms of process monitoring, basic concepts for MM PBF-LB have been identified. Process understanding, however, needs to be deepened and monitoring solutions need to improve to be transferred to industrial applications.

In the post-processing, cross-contamination for the metal powder is investigated. Here, the literature is reviewed on separation principles that have been tested exemplarily on specific combinations of materials. Ferromagnetic particle separation and sorting based on particle size via screening are already in use in laboratory applications. Further process steps to finalize a MM part (e.g., heat treatment, machining) are not discussed in the analyzed literature, despite MM parts requiring an adjusted process chain to obtain technical functionality.

Economic aspects for MM parts are difficult to assess, because of the current state of technology maturity. In several process steps, the effort for manufacturing a serial MM part is unclear e.g., machine runtime when utilizing a MM application device, conditions, and quality of powder separation techniques [83]\}. Hence, a cost estimation for MM parts must be based on vague estimations. Nevertheless, it can be stated, that the additional efforts required to produce MM parts will cause costs, which exceed the current costs of the PBF-LB process for mono-material parts.

In conclusion, multi-material manufacturing offers the potential to utilize different materials on a local level within a part. PBF processes demonstrated the capability to produce such parts. However, the overall technology maturity of 3D-MM in PBF is assessed as manufacturing readiness level 4-5 \{MRL; defined in [25]\}, which can be considered as pacemaker technology. A 2D hybrid manufacturing approach is already utilized for serial products, thus it has a MRL of 7-9. The 2D full AM approach has a MRL of 6-7 (see Table 2). In a study from 2017, $60 \%$ of participants stated that MM manufacturing by PBF will not be technically feasible prior to 2026 [84]. Thus the development of MM manufacturing by PBF is expected to cover at least a 10 year timespan.

The further development of MM technologies must be driven by applications utilizing the benefits of MM parts, which will cause AM system manufacturer to develop appropriate manufacturing systems. Considering the development of the PBF-LB process, it is expected that such applications can be identified at first in the medical and aerospace sector. This comprehensive review of MM in PBF processes supports this identification by summarizing the state of research in materials, MM deposition devices, and the implications for the process chain. 


\section{Appendix}

Table 3 Literature sources for 2D multi-materials

\begin{tabular}{|c|c|c|c|c|c|}
\hline \multicolumn{2}{|c|}{ MM approach } & \multirow{2}{*}{$\begin{array}{l}\text { Reference } \\
\text { Bai et al. [85] }\end{array}$} & \multirow{2}{*}{$\begin{array}{l}\text { Deposi- } \\
\text { tion } \\
\text { approach }\end{array}$} & \multirow{2}{*}{$\begin{array}{l}\text { Material A } \\
\text { (hybrid: conv. material) }\end{array}$} & \multirow{2}{*}{$\begin{array}{l}\text { Material B } \\
\text { Fe (MS 1) }\end{array}$} \\
\hline \multirow{17}{*}{\multicolumn{2}{|c|}{$\begin{array}{c}\text { 2D AM on conventional material } \\
\text { (hybrid approach) }\end{array}$}} & & & & \\
\hline & & Tan et al. [86] & & $\mathrm{Cu}(\mathrm{C} 11000)$ & $\mathrm{Fe}(\mathrm{MS} \mathrm{C} 300)$ \\
\hline & & Tan et al. [87] & & $\begin{array}{l}\mathrm{Fe}(\mathrm{CS} 45) \\
\mathrm{Fe}(\mathrm{SS} 304)\end{array}$ & $\mathrm{Fe}(\mathrm{MS} \mathrm{C} 300)$ \\
\hline & & Bhaduri et al. [88] & & $\mathrm{Al}(\mathrm{AA} 6082)$ & $\mathrm{Al}(\mathrm{A} 1 \mathrm{Si} 10 \mathrm{Mg})$ \\
\hline & & Jurisch et al. ${ }^{a}[29]$ & & $\mathrm{Fe}(1.2343)$ & $\mathrm{Fe}(\mathrm{FeCr} 10 \mathrm{~V})$ \\
\hline & & Nguyen et al. [89] & & $\mathrm{Fe}(316 \mathrm{~L})$ & $\mathrm{Al}$ (pure) \\
\hline & & Tan et al. [90] & & $\mathrm{Cu}$ & $\mathrm{W}$ (pure) \\
\hline & & Shakerin et al. [91] & & $\mathrm{Fe}(\mathrm{H} 13)$ & $\mathrm{Fe}(\mathrm{MS} 1)$ \\
\hline & & Cyr et al. [92] & & $\mathrm{Fe}(\mathrm{H} 13)$ & $\mathrm{Fe}(\mathrm{MS} 1)$ \\
\hline & & Leuteritz et al. [93] & & $\begin{array}{l}\mathrm{Al}(\text { casted Al-7075) } \\
\mathrm{Al} \text { (casted Al-6082) }\end{array}$ & $\begin{array}{l}\mathrm{Al}(\mathrm{AlSi} 10 \mathrm{Mg}) \\
\mathrm{Al}(\mathrm{AlSi} 10 \mathrm{Mg})\end{array}$ \\
\hline & & Link et al. [27] & & $\mathrm{Fe}(1.4301)$ & $\mathrm{Fe}(1.4404)$ \\
\hline & & Santos et al. [94] & & $\begin{array}{l}\mathrm{Fe}(\text { AISI H13) } \\
\mathrm{Fe} \text { (stainless steel AISI 420) }\end{array}$ & $\mathrm{Fe}(\mathrm{AISI} 18 \mathrm{Ni300})$ \\
\hline & & Tan et al. [87] & & $\mathrm{Cu}$ & $\mathrm{Fe}$ (maraging steel) \\
\hline & & Zghair and Lachmayer [95] & & $\begin{array}{l}\mathrm{Al} \text { (casted Al-7075) } \\
\mathrm{Al} \text { (casted Al-6082) }\end{array}$ & $\begin{array}{l}\mathrm{Al}(\mathrm{AlSi} 10 \mathrm{Mg}) \\
\mathrm{Al}(\mathrm{AlSi} 10 \mathrm{Mg})\end{array}$ \\
\hline & & Hallmann et al. [96] & & $\begin{array}{l}\mathrm{Fe}(1.4301) \\
\mathrm{Fe}(1.0330)\end{array}$ & $\begin{array}{l}\mathrm{Fe}(1.2709) \\
\mathrm{Fe}(1.2709)\end{array}$ \\
\hline & & Wallis et al. [97] & & $\mathrm{Cu}(2.0090)$ & $\mathrm{Fe}(1.2709)$ \\
\hline & & Yeong and Chen [98] & & $\mathrm{Fe}(316 \mathrm{~L})$ & $\mathrm{Cu}$ (Hovadur K220) \\
\hline \multirow{15}{*}{\multicolumn{2}{|c|}{ Full AM }} & Wits and Amsterdam [99] & & $\mathrm{Fe}(316 \mathrm{~L})$ & $\mathrm{Ni}(\operatorname{In} 718)$ \\
\hline & & Chen et al. [100] & & $\mathrm{Fe}(316 \mathrm{~L})$ & $\mathrm{Cu}(\mathrm{CuSn} 10)$ \\
\hline & & Nadimpalli et al. [101] & N/AF & $\mathrm{Fe}(440 \mathrm{C})$ & $\mathrm{Fe}(316 \mathrm{~L})$ \\
\hline & & Yusuf et al. [102] & & $\mathrm{Fe}(316 \mathrm{~L})$ & Ni (IN718) \\
\hline & & Schmid [103] & MF & $\mathrm{Al}$ (AlSi12) & $\operatorname{Mg}(A Z 91)$ \\
\hline & & Chueh et al. [104, 105] & $\mathrm{N}$ & $\mathrm{Fe}(316 \mathrm{~L})$ & $\begin{array}{l}\text { Polymer (PLA, PET) } \\
\mathrm{Cu}(\mathrm{CuSn} 10)\end{array}$ \\
\hline & & Hansen et al. [106] & N/AF & $\mathrm{Fe}(316 \mathrm{~L})$ & $\mathrm{Fe}(\mathrm{MS} 1)$ \\
\hline & & Koopmann et al. [107] & & Fe (X38CrMoV5-3) & Ceramic $\left(\mathrm{ZrO}_{2}-\mathrm{Al}_{2} \mathrm{O}_{3}\right)$ \\
\hline & & Nadimpalli et al. [108] & N/AF & $\mathrm{Fe}(316 \mathrm{~L})$ & $\mathrm{Fe}(\mathrm{MS} 1)$ \\
\hline & & Demir and Previtali [109] & $\mathrm{AF}$ & $\mathrm{Fe}$ (pure) & $\begin{array}{l}\text { Fe-Al-mixture (55/45) } \\
\mathrm{Al}(\mathrm{AlSi} 12)\end{array}$ \\
\hline & & Sing et al. [77] & $\mathrm{C}$ & $\mathrm{Al}(\mathrm{AlSi} 10 \mathrm{Mg})$ & $\mathrm{Cu}(\mathrm{C} 18400)$ \\
\hline & & Liu et al. [110] & $\mathrm{C}$ & $\mathrm{Fe}(316 \mathrm{~L})$ & $\mathrm{Cu}(\mathrm{C} 18400)$ \\
\hline & & Beal et al. ${ }^{b}[31]$ & $\mathrm{C}$ & $\mathrm{Fe}(\mathrm{H} 13)$ & $\mathrm{Fe}-\mathrm{Cu}$-mixture (50/50) \\
\hline & & Mumtaz and Hopkinson [111] & & Ni (Waspalloy) & Ni-ceramic-mixture $(90 / 10)$ \\
\hline & & Regenfuss et al. ${ }^{\mathrm{c}}[30]$ & $\mathrm{C}$ & $\mathrm{Ag}$ & $\mathrm{Cu}$ \\
\hline
\end{tabular}

$M F$ manual feedstock change, $A F$ automated feedstock change, $N$ Nozzle-based concept, $C$ coater-based concept ${ }^{\mathrm{a}} \mathrm{PBF}-\mathrm{EB}$ process

${ }^{\mathrm{b}}$ Material transition along coater axis

${ }^{\mathrm{c}}$ Micro PBF-LB process 
Table 4 Literature sources for 3D multi-materials

\begin{tabular}{|c|c|c|c|c|c|}
\hline \multicolumn{2}{|c|}{ MM approach } & \multirow{2}{*}{$\begin{array}{l}\text { Reference } \\
\text { Gerstgrasser et al. [34] }\end{array}$} & \multirow{2}{*}{$\begin{array}{l}\text { Deposi- } \\
\text { tion } \\
\text { approach }\end{array}$} & \multirow[t]{2}{*}{ Material A } & \multirow[t]{2}{*}{ Material B } \\
\hline $3 \mathrm{D}$ & Theoretical concept & & & & \\
\hline \multirow{2}{*}{\multicolumn{2}{|c|}{ Layer deposition demonstrated }} & Chianrabutra et al. [32] & $\mathrm{N}$ & $\begin{array}{l}\text { 316L, } \mathrm{SiC}, \mathrm{CoCr}, \mathrm{Cu} \text {, glass, } \\
\text { 420S45, WC, } \mathrm{Al} 2 \mathrm{O} 3 \text {, glass- } \\
\text { filled } \mathrm{PA}, \mathrm{SnPb}\end{array}$ & \\
\hline & & van der Eijk et al. [33] & $\mathrm{P}$ & $\mathrm{Fe}$ & $\mathrm{Cu}$ \\
\hline \multirow{12}{*}{\multicolumn{2}{|c|}{ Exemplary part built }} & $\begin{array}{l}\text { Anstaett [19], Anstaett et al. } \\
\text { [38], Anstaett et al. [37], } \\
\text { Anstaett et al. [36] }\end{array}$ & $\mathrm{S}$ & $\begin{array}{l}\mathrm{Fe}(1.2709) \\
\mathrm{Al}(\text { EN AC-43400) }\end{array}$ & $\begin{array}{l}\mathrm{Cu}(\mathrm{CW} 106 \mathrm{C}) \\
\mathrm{Cu}(\mathrm{CW} 106 \mathrm{C})\end{array}$ \\
\hline & & Koopmann [16] & $\mathrm{N}$ & $\mathrm{Fe}(\mathrm{X} 38 \mathrm{CrMoV5}-3)$ & $\begin{array}{r}\text { Ceramic }\left(\mathrm{ZrO}_{2}-\mathrm{Al}_{2} \mathrm{O}_{3}\right) \mathrm{Cu} \\
(\mathrm{CuNi} 44 \mathrm{Mn} 1, \mathrm{Cu}-\mathrm{DHP})\end{array}$ \\
\hline & & Girnth et al. [15] & $\mathrm{N}$ & $\begin{array}{l}\mathrm{Fe} \\
\mathrm{Fe}\end{array}$ & $\begin{array}{l}\mathrm{Cu} \\
\text { ceramic }\end{array}$ \\
\hline & & VDI [46] & & $\mathrm{Fe}(1.2709)$ & $\mathrm{Cu}(\mathrm{CW} 106 \mathrm{C})$ \\
\hline & & Wei et al. [51] & NA & $\mathrm{Fe}(316 \mathrm{~L})$ & $\mathrm{Cu}(\mathrm{CuSn} 10)$ \\
\hline & & Zhang et al. [50] & $\mathrm{N}$ & $\begin{array}{l}\mathrm{Fe}(316 \mathrm{~L}) \\
\mathrm{Cu}(\mathrm{CuSn} 10)\end{array}$ & $\begin{array}{l}\text { Glass (soda-lime) } \\
\text { glass (soda-lime) }\end{array}$ \\
\hline & & Binder et al. [112] & $\mathrm{S}$ & $\mathrm{Fe}(1.2709)$ & $\mathrm{Cu}(\mathrm{CW} 106 \mathrm{C})$ \\
\hline & & Wei et al. [52] & $\mathrm{N}$ & $\mathrm{Fe}(316 \mathrm{~L})$ & $\begin{array}{l}\mathrm{Cu}(\mathrm{CuSn} 10) \\
\mathrm{Ni}(\mathrm{IN} 718) \\
\mathrm{SiC}\end{array}$ \\
\hline & & Kordaß et al. [48] & $\mathrm{N}$ & $\mathrm{Fe}(316 \mathrm{~L})$ & $\mathrm{Cu}$ (paste: heraeus C7404A) \\
\hline & & Chivel [76] & $\mathrm{S}$ & Fe (inox) & $\mathrm{Cu}$ \\
\hline & & Ott [18] & $\mathrm{N}$ & $\mathrm{Fe}(1.2709)$ & WCCo \\
\hline & & Al-Jamal et al. [53] & $\mathrm{N}$ & $\mathrm{Fe}(\mathrm{H} 13)$ & $\mathrm{Cu}$ \\
\hline
\end{tabular}

$N A$ nozzle array concept, $N$ nozzle concept, $P$ photoconductor (masked), $S$ suction concept (holohedral)

Acknowledgements The authors express their sincere thanks to the Freistaat Bayern and its Bavarian Ministry of Economic Affairs, Energy and Technology for funding the "MULTIMATERIALZENTRUM Augsburg." The open access publication is granted by the DEAL project.

Author contributions MS: conceptualization; methodology; formal analysis; investigation; writing —original draft. MH: conceptualization; methodology; formal analysis; investigation; writing—original draft. MS: writing — review and editing; resources. CS: writing — review and editing; funding acquisition. GS: supervision. GR: supervision; funding acquisition.

Funding Open Access funding enabled and organized by Projekt DEAL.

\section{Declarations}

Conflict of interest The authors state, that there are no conflict of interest with the content of this manuscript.

Open Access This article is licensed under a Creative Commons Attribution 4.0 International License, which permits use, sharing, adaptation, distribution and reproduction in any medium or format, as long as you give appropriate credit to the original author(s) and the source, provide a link to the Creative Commons licence, and indicate if changes were made. The images or other third party material in this article are included in the article's Creative Commons licence, unless indicated otherwise in a credit line to the material. If material is not included in the article's Creative Commons licence and your intended use is not permitted by statutory regulation or exceeds the permitted use, you will need to obtain permission directly from the copyright holder. To view a copy of this licence, visit http://creativecommons.org/licenses/by/4.0/.

\section{References}

1. Mahamood RM, Akinlabi ET, Shukla M, Pityana S (2012) Functionally graded material: an overview. In lecture notes in engineering and computer science, 4-6 July, 2012, Imperial College London, London, UK/organized by association, IAENG, international association of engineers. In: Ao SI (ed) The 2012 international conference of manufacturing engineering and engineering management, the 2012 international conference of mechanical engineering, international association of engineers, vol 3. IAENG, Hong Kong

2. Pei E et al (2017) A study of 4D printing and functionally graded additive manufacturing. Assem Autom. https://doi.org/10.1108/ AA-01-2017-012

3. El-Galy IM, Saleh BI, Ahmed MH (2019) Functionally graded materials classifications and development trends from 
industrial point of view. Appl Sci. https://doi.org/10.1007/ s42452-019-1413-4

4. Schleifenbaum JH et al (2019) Future AM. In: Neugebauer R (ed) Biologische transformation. Springer, Berlin, pp 229-250. https://doi.org/10.1007/978-3-662-58243-5

5. Wohlers T et al (2020) Wohlers report 2020. Fort Collins, Colorado $(\mathbf{9 7 8 0 9 9 1 3 3 3 2 6 4 )}$

6. ISO/ASTM 52900:2015 Additive manufacturing—general principles - terminology. https://www.iso.org/standard/69669.html

7. Reichardt A et al (2021) Advances in additive manufacturing of metal-based functionally graded materials. Int Mater Rev. https:// doi.org/10.1080/09506608.2019.1709354

8. Popov VV, Fleisher A (2020) Hybrid additive manufacturing of steels and alloys. Manufacturing Rev. https://doi.org/10.1051/ mfreview/2020005

9. Yang S, Zhao YF (2015) Additive manufacturing-enabled design theory and methodology: a critical review. Int J Adv Manuf Technol. https://doi.org/10.1007/s00170-015-6994-5

10. Pei E et al (2021) Functionally graded additive manufacturing. In: Singh S, Hussain CM (eds) Additive manufacturing with functionalized nanomaterials. Elsevier, Amsterdam, pp 35-54 (10.1016/B978-0-12-823152-4.00006-5)

11. Wei $C$ et al (2020) An overview of laser-based multiple metallic material additive manufacturing: from macro- to micro-scales. Int J Extrem Manuf. https://doi.org/10.1088/2631-7990/abce04

12. Zhang et al (2019) Additive manufacturing of functionally graded materials: a review. Mater Sci Eng. https://doi.org/10.1016/j. msea.2019.138209

13. Bandyopadhyay A, Heer B (2018) Additive manufacturing of multi-material structures. Mater Sci Eng. https://doi.org/10. 1016/j.mser.2018.04.001

14. ISO/ASTM TR 52912:2020 Additive manufacturing—designfunctionally graded additive manufacturing. https://www.iso.org/ standard/71905.html

15. Girnth S et al (2019) 3D hybrid-material processing in selective laser melting: implementation of a selective coating system. Prog Addit Manuf. https://doi.org/10.1007/s40964-019-00082-w

16. Koopmann J (2019) Multimaterialdruck von integrierten elektrischen Strukturen mittels selektivem Laserschmelzen. Dissertation, Universitaet Kassel. https://doi.org/10.19211/KUP9783737 608138

17. Vaezi M, Chianrabutra S, Mellor B, Yang S (2013) Multiple material additive manufacturing — part 1: a review. Virtual Phys Prototyp. https://doi.org/10.1080/17452759.2013.778175

18. Ott M (2012) Multimaterialverarbeitung bei der additiven strahlund pulverbettbasierten Fertigung. Dissertation, Technische Universitaet Muenchen

19. Anstaett C (2020) Multimaterialverarbeitung mittels Laserstrahlschmelzen am Beispiel von metallischen Verbindungen mit der Kupferlegierung CW106C. Dissertation, Technische Universitaet Muenchen

20. Tammas-Williams S, Todd I (2016) Design for additive manufacturing with site-specific properties in metals and alloys. Scripta Mater. https://doi.org/10.1016/j.scriptamat.2016.10.030

21. Hofmann DC et al (2014) Compositionally graded metals: a new frontier of additive manufacturing. J Mater Res. https://doi.org/ 10.1557/jmr.2014.208

22. ISO/ASTM 52921:2013 Standard terminology for additive manufacturing - coordinate systems and test methodologies. https:// www.iso.org/standard/62794.html

23. Schaub A, Juechter V, Singer RF, Merklein M (2014) Characterization of hybrid components consisting of SEBM additive structures and sheet metal of alloy Ti-6Al-4V. Key Eng Mater 611-612:609-614
24. Klocke F et al (2017) State-of-the-art laser additive manufacturing for hot-work tool steels. Procedia CIRP. https://doi.org/10. 1016/j.procir.2017.03.073

25. Department of Defence/DoD (2018) Manufacturing readiness level (MRL) deskbook. Available online: http://www.dodmrl. com. Accessed: 19 Oct 2017

26. ISO 16290:2013 Space systems-definition of the technology readiness levels (TRLs) and their criteria of assessment. https:// www.iso.org/standard/56064.html

27. Link M, Haefele T, Abele E (2018) Examination of the connection between selective laser-melted components made of $316 \mathrm{~L}$ steel powder on conventionally fabricated base bodies. Proceedings of the Solid Freeform Fabrication SFF 2018

28. Anstaett C, Seidel C, Reinhart G (2016) Multi-material fabrication of Copper-Chrome-Zirconia and tool steel 1.2709 by powder bed based laser beam melting. In: Fraunhofer direct digital manufacturing conference DDMC 2016, ISBN 978-3-8396-1001-5

29. Jurisch $\mathrm{M}$ et al (2019) Processing of FeCrV-steels by selective electron beam melting (SEBM). Proceedings of the EuroPM 2019

30. Regenfuss P et al (2007) Principles of laser micro sintering. Rapid Prototy J. https://doi.org/10.1108/13552540710776151

31. Beal VE, Erasenthiran P, Ahrens CH, Dickens P (2007) Evaluating the use of functionally graded materials inserts produced by selective laser melting on the injection moulding of plastics parts. Proc Inst Mech Eng. https://doi.org/10.1243/09544054JE M764

32. Eijk vdC et al (2005) Metal printing process: a rapid manufacturing process based on xerography using metal powders. Mater Sci Technol 5:25-28

33. Chianrabutra S, Mellor B, Yang S (2014) A dry powder material delivery device for multiple material additive manufacturing. Proceedings of the solid freeform fabrication SFF 2014

34. Gerstgrasser M, Maier M, Borinelli J, Wegener K (2019) New concept for multi-material processing with SLM. Proceedings of lasers in manufacturing conference 2019

35. Neirinck B, Li X, Hick M (2021) Powder deposition systems used in powder bed-based multimetal additive manufacturing. Acc Mater Res. https://doi.org/10.1021/accountsmr.1c00030

36. Anstaett C, Seidel C (2016) Multi-material processing. Laser Tech J. https://doi.org/10.1002/latj.201600027

37. Anstaett C, Seidel C, Reinhart G (2017) Fabrication of 3D-multimaterial parts by laser beam based powder bed fusion. Proceedings of the solid freeform fabrication SFF 2017

38. Anstaett C, Seidel C, Reinhart G (2018) Herstellung von 3-D-Multimaterialbauteilen aus Kupfer-Chrom-Zirkonium und Werkzeugstahl 12709. In: Kynast M, Eichmann M, Witt G (eds) Proceedings of the 15th rapid tech conference, Erfurt, pp 330344. https://doi.org/10.3139/9783446458123

39. Lindemann C (2017) Systematic approach for cost efficient design and planning with additive manufacturing. Dissertation, Universitaet Paderborn. ISBN 978-3-8440-5718-8

40. Kamps $\mathrm{T}$ et al (2018) Cost- and energy-efficient manufacture of gears by laser beam melting. CIRP J Manuf Sci Technol. https:// doi.org/10.1016/j.cirpj.2018.01.002

41. Spierings AB, Levy G (2009) Comparison of density of stainless steel $316 \mathrm{~L}$ parts produced with selective laser melting using different powder grades. Proceedings of the Solid Freeform Fabrication SFF 2009

42. Lutter-Guenther M, Horn M, Seidel C, Reinhart G (2017) Influence of particle size distribution on powder flowability and part properties in laser beam melting. In: Kynast M, Eichmann M, Witt G (eds) Proceedings of the 14th Rapid.Tech Conference Erfurt, Germany, pp 297-311. https://doi.org/10.3139/97834 46454606 
43. Wischeropp TM, Emmelmann C, Brandt M, Pateras A (2019) Measurement of actual powder layer height and packing density in a single layer in selective laser melting. Addit Manuf. https:// doi.org/10.1016/j.addma.2019.04.019

44. Ghouse $\mathrm{S}$ et al (2017) The influence of laser parameters and scanning strategies on the mechanical properties of a stochastic porous material. Mater Des. https://doi.org/10.1016/j.matdes. 2017.06.041

45. Anstaett C, Schafnitzel M, Seidel C, Reinhart G (2017) Laserbased powder bed fusion Of 3D-multi-material-parts of copper chrome-zirconia and tool steel. Proceedings of the EuroPM 2017

46. VDI (2019) Additive Fertigung-Statusreport 2019. Available online: https://www.vdi.de/ueber-uns/presse/publikationen/detai 1s/3-d-druckverfahren-sind-realitaet-in-der-industriellen-ferti gung. Accessed 15 Nov 2020

47. Pegna J et al (1999) The sand-painter: two-dimensional powder deposition. Proceedings of the solid freeform fabrication SFF 1999

48. Kordaß R, Jaretzki M, Dani I (2017) Entwicklung eines Systems zur kontaminationsfreien Multimaterialfertigung beim LaserStrahlschmelzen. In: M. Kynast M, Witt G, Eichmann M (eds) Proceedings of the 14th rapid tech conference, Erfurt, Germany. Hanser, München. https://doi.org/10.3139/9783446454606

49. Kordaß R, Dani I (2016) Method and device for the generative production of three-dimensional composite components. German Patent DE 102016208196 B4.

50. Zhang X, Wei C, Chueh YH, Li L (2019) An integrated dual ultrasonic selective powder dispensing platform for three-dimensional printing of multiple material metal/glass objects in selective laser melting. J Manuf Sci Eng. https://doi.org/10.1115/1. 4041427

51. Wei C et al (2019) Additive manufacturing of horizontal and $3 \mathrm{D}$ functionally graded $316 \mathrm{~L} / \mathrm{Cu} 10 \mathrm{Sn}$ components via multiple material selective laser melting. J Manuf Sci Eng. https://doi.org/ $10.1115 / 14043983$

52. Wei C, Li L, Zhang X, Chueh YH (2018) 3D printing of multiple metallic materials via modified selective laser melting. CIRP Ann. https://doi.org/10.1016/j.cirp.2018.04.096

53. Al-Jamal OM, Hinduja S, Li L (2008) Characteristics of the bond in $\mathrm{Cu}-\mathrm{H} 13$ tool steel parts fabricated using SLM. CIRP Ann. https://doi.org/10.1016/j.cirp.2008.03.010

54. Bedoret A, Hick M, Eckes K (2016) Device and method for creating a particle structure. Patent BE1024613B1, Belgium

55. Aerosint SA (2020) How multi-powder deposition will transform industrial 3D printing. Available online: https://aerosint. com/powder-deposition-multimaterial-printing/ Accessed 15 Nov 2020

56. Aerosint SA (2020) The 3 most promising use cases for selective powder deposition. Available online: https://aerosint.com/the3-most-promising-use-cases-for-selective-powder-deposition/ Accessed 15 Nov 2020

57. Aerosint SA (2020) Aerosint zeigt Multi-Metall-3D-Druck. Available online: https://3druck.com/industrie/aerosint-zeigtmulti-metall-3d-druck-1991944/, Accessed 15 Nov 2020

58. Technical guideline VDI 3405:2014: Additive manufacturing processes, rapid manufacturing — basics, definitions, processes

59. Pradel P, Zhu Z, Bibb R, Moultrie J (2018) A framework for mapping design for additive manufacturing knowledge for industrial and product design. J Eng Des. https://doi.org/10.1080/09544 828.2018.1483011

60. Laverne F, Segonds F, D'Antonio G, Le Coq M (2017) Enriching design with $\mathrm{X}$ through tailored additive manufacturing knowledge: a methodological proposal. Int J Interact Des Manuf. https://doi.org/10.1007/s12008-016-0314-7
61. Loh GH, Pei E, Harrison D, Monzón MD (2018) An overview of functionally graded additive manufacturing. Addit Manuf. https://doi.org/10.1016/j.addma.2018.06.023

62. Yao X, Moon SK, Bi G, Wei J (2018) A multi-material part design framework in additive manufacturing. Int $\mathbf{J}$ Adv Manuf Technol. https://doi.org/10.1007/s00170-018-2025-7

63. Altenhofen $\mathrm{C}$ et al (2018) Continuous property gradation for multi-material 3D-printed objects. Proceedings of the solid freeform fabrication SFF 2018

64. Zuo W, Saitou K (2017) Multi-material topology optimization using ordered SIMP interpolation. Struct Multidisc Optim. https://doi.org/10.1007/s00158-016-1513-3

65. Binder $\mathrm{M}$ et al (2018) Potentials and challenges of multi-material processing by laser-based powder bed fusion. Proceedings of the solid freeform fabrication SFF 2018

66. Wei $\mathrm{C}$ et al (2021) Understanding of process and material behaviours in additive manufacturing of Invar36/Cu10Sn multiple material components via laser-based powder bed fusion. Addit Manuf. https://doi.org/10.1016/j.addma.2020.101683

67. Rankouhi B, Jahani S, Pfefferkorn FE, Thoma DJ (2021) Compositional grading of a 316L-Cu multi-material part using machine learning for the determination of selective laser melting process parameters. Addit Manuf. https://doi.org/10.1016/j.addma.2021. 101836

68. Küng VE, Scherr R, Markl M, Körner C (2021) Multi-material model for the simulation of powder bed fusion additive manufacturing. Comput Mater Sci. https://doi.org/10.1016/j.comma tsci.2021.110415

69. Gu H et al (2020) Multi-physics modelling of molten pool development and track formation in multi-track, multi-layer and multimaterial selective laser melting. Int J Heat Mass Transf. https:// doi.org/10.1016/j.ijheatmasstransfer.2020.119458

70. Sun $\mathrm{H}$ et al (2021) Selective laser melting for joining dissimilar materials: investigations of interfacial characteristics and in situ alloying. Metall Mater Trans A. https://doi.org/10.1007/ s11661-021-06178-9

71. Sing SL et al (2021) Emerging metallic systems for additive manufacturing: in-situ alloying and multi-metal processing in laser powder bed fusion. Prog Mater Sci. https://doi.org/10.1016/j. pmatsci.2021.100795

72. Kleszczynski S, zur Jacobsmuehlen J, Sehrt J, Witt G (2012) Error detection in laser beam melting systems by high resolution imaging. Proceedings of the solid freeform fabrication SFF 2012

73. Jamshidinia $\mathrm{M}$ et al (2016) In-process monitoring of cross contamination in laser Powder bed fusion (L-PBF) additive manufacturing (AM). Proceedings of the solid freeform fabrication SFF 2016

74. Horn $\mathrm{M}$ et al (2020) Influence of metal powder cross-contaminations on part quality in laser powder bed fusion: copper alloy particles in maraging steel feedstock. Procedia CIRP. https://doi. org/10.1016/j.procir.2020.09.032

75. Horn $\mathrm{M}$ et al (2018) Powder separation strategies for recycling in multi-material additive manufacturing. Proceedings of the EuroPM 2018

76. Chivel Y (2016) New approach to multi-material processing in selective laser melting. Phys Procedia. https://doi.org/10.1016/j. phpro.2016.08.093

77. Sing SL et al (2015) Interfacial characterization of SLM parts in multi-material processing: intermetallic phase formation between AlSi10Mg and C18400 copper alloy. Mater Charact. https://doi. org/10.1016/j.matchar.2015.07.007

78. Santecchia E et al (2019) Enhancing the quality of metal powder feedstock for laser PBF through cross-contamination removal. Proceedings of the Euro PM2019 Congress and Exhibition 
79. Horn M et al (2020) Multi-material additive manufacturing: metal powder recycling via sedimentation. Proceedings of the EuroPM 2020

80. MAPAL Praezisionswerkzeuge Dr. Kress KG (2020) Mit additiver Fertigung zu mehr Produktivitaet. Available online: https:// www.mapal.com/fileadmin/00_PDF-Dateien/2_Aktuelles/Press eberichte_deutsch/2020/2020-01-17_Additive_Fertigung_Glock enwerkzeug.pdf. Accessed 15 Nov 2020

81. Pohle C (1999) Schweissen von Werkstoffkombinationen: Metallkundliche und fertigungstechnische Grundlagen sowie Ausfuehrungsbeispiele. Verlag fuer Schweissen und Verwandte Verfahren DVS-Verlag, Duesseldorf

82. Bajaj P et al (2020) Steels in additive manufacturing: a review of their microstructure and properties. Mater Sci Eng. https://doi. org/10.1016/j.msea.2019.138633

83. Lutter-Guenther M (2020) Qualitaetsorientiertes und modellbasiertes Pulverrecycling beim Laserstrahlschmelzen. Dissertation (PhD thesis), Technisch Universitaet Muenchen. Available online: https://mediatum.ub.tum.de/doc/1525783/1525783.pdf. Accessed 22 June 2021

84. Lanza G et al (2017) Laser-Strahlschmelzen-Technologie mit Zukunftspotenzial: Ein Handlungsleitfaden. KIT-Karlsruhe Institut fuer Technologie, wbk Institut fuer Produktionstechnik. ISBN 978-3-00-056913-5

85. Bai Y, Zhao C, Zhang Y, Wang H (2020) Microstructure and mechanical properties of additively manufactured multi-material component with maraging steel on CrMn steel. Mater Sci Eng. https://doi.org/10.1016/j.msea.2020.140630

86. Tan C et al (2020) Additive manufacturing of steel-copper functionally graded material with ultrahigh bonding strength. J Mater Sci Technol. https://doi.org/10.1016/j.jmst.2020.07.044

87. Tan C, Wang D, Ma W, Zhou K (2021) Ultra-strong bond interface in additively manufactured iron-based multi-materials. Mater Sci Eng. https://doi.org/10.1016/j.msea.2020.140642

88. Bhaduri D et al (2019) Evaluation of surface/interface quality, microstructure and mechanical properties of hybrid additive-subtractive aluminium parts. CIRP Ann. https://doi.org/10.1016/j. cirp.2019.04.116

89. Nguyen DS, Park HS, Lee CM (2019) Applying selective laser melting to join $\mathrm{Al}$ and $\mathrm{Fe}$ : an investigation of dissimilar materials. Appl Sci. https://doi.org/10.3390/app9153031

90. Tan C, Zhou K, Kuang T (2019) Selective laser melting of Tungsten-Copper functionally graded material. Mater Lett. https://doi. org/10.1016/j.matlet.2018.11.127

91. Shakerin $\mathrm{S}$ et al (2019) Additive manufacturing of maraging steel-H13 bimetals using laser powder bed fusion technique. Addit Manuf. https://doi.org/10.1016/j.addma.2019.100797

92. Cyr E et al (2018) Fracture behaviour of additively manufactured MS1-H13 hybrid hard steels. Mater Lett. https://doi.org/ 10.1016/j.matlet.2017.10.097

93. Leuteritz G, Demminger C, Maier HJ, Lachmayer R (2018) Hybride additive fertigung: Ansaetze zur Kombination von additiven und giesstechnischen Fertigungsverfahren fuer die Serienfertigung. In: Lachmayer R, Lippert RB, Kaierle S (eds) Additive Serienfertigung. Springer, Berlin Heidelberg, pp 115-126 (10.1007/978-3-662-56463-9)

94. Santos L et al (2018) Fracture toughness of hybrid components with selective laser melting $18 \mathrm{Ni300}$ steel parts. Appl Sci. https://doi.org/10.3390/app8101879

95. Zghair YA, Lachmayer R (2018) Additive repair design approach: case study to repair aluminum base components. In: Maier A, Škec S, Kim H, Kokkolaras M, Oehmen J, Fadel G, Salustri F, Vander Loos M (eds) International conference on engineering design. Vancouver, Canada, pp 141-150. ISBN 978-1-904670-93-3

96. Hallmann S et al (2016) Process development for hybrid punching dies by selective laser melting of steel material. Proc of the iCAT 2016:362-367

97. Wallis C, Buchmayr B, Kitzmantel M, Brandstaetter E (2016) Additive manufacturing of maraging steel on a copper substrate using selective laser melting. 2nd Metal additive manufacturing conference, Linz

98. Yeong WY, Chen S (2016) Selective laser melting of copper based alloy on steel: a preliminary study. 2nd International conference on progress in additive manufacturing (Pro-AM 2016), Singapore

99. Wits WW, Amsterdam E (2021) Graded structures by multimaterial mixing in laser powder bed fusion. CIRP Ann. https:// doi.org/10.1016/j.cirp.2021.03.005

100. Chen J, Yang Y, Wang D, Liu Z, Song C (2021) Effect of manufacturing steps on the interfacial defects of laser powder bed fusion 316L/CuSn10. Mater Lett. https://doi.org/10.1016/j.matlet.2021.129377

101. Nadimpalli VK et al (2021) Interface engineering of functionally graded steel-steel composites by laser powder bed fusion. Manufacturing Letters. https://doi.org/10.1016/j.mfglet.2021.03. 003

102. Yusuf SM, Zhao X, Yang S, Gao N (2020) Interfacial characterisation of multi-material 316L stainless steel/Inconel 718 fabricated by laser powder bed fusion. Mater Lett. https://doi.org/10. 1016/j.matlet.2020.128928

103. Schmid D (2020) Untersuchungen zum Laserstrahlschmelzen von Magnesiumlegierungen. Dissertation, Technisch Universitaet Muenchen

104. Chueh YH et al (2020) Additive manufacturing of hybrid metal/ polymer objects via multiple-material laser powder bed fusion. Addit Manuf. https://doi.org/10.1016/j.addma.2020.101465

105. Chueh YH, Wei C, Zhang X, Li L (2019) Integrated laser-based powder bed fusion and fused filament fabrication for threedimensional printing of hybrid metal/polymer objects. Addit Manuf. https://doi.org/10.1016/j.addma.2019.100928

106. Hansen $\mathrm{HN}$ et al (2019) Additive manufacturing of metal components-process-material interaction in different process chains. Mater Sci Eng. https://doi.org/10.1088/1757-899X/580/1/012006

107. Koopmann J, Voigt J, Niendorf T (2019) Additive manufacturing of a steel-ceramic multi-material by selective laser melting. Metall Materi Trans B. https://doi.org/10.1007/s11663-019-01523-1

108. Nadimpalli VK et al (2019) Multi-material additive manufacturing of steels using laser powder bed fusion. Proceedings of the 19th international conference and exhibition (EUSPEN 2019). Bilbao, pp 240-243

109. Demir AG, Previtali B (2017) Multi-material selective laser melting of Fe/Al-12Si components. Manuf Lett. https://doi.org/10. 1016/j.mfglet.2017.01.002

110. Liu ZH et al (2014) Interfacial characterization of SLM parts in multi-material processing: metallurgical diffusion between $316 \mathrm{~L}$ stainless steel and C18400 copper alloy. Mater Charact. https:// doi.org/10.1016/j.matchar.2014.05.001

111. Mumtaz KA, Hopkinson N (2007) Laser melting functionally graded composition of Waspaloy ${ }^{\circledR}$ and zirconia powders. J Mater Sci. https://doi.org/10.1007/s10853-007-1661-3

112. Binder $\mathrm{M}$ et al (2018) Automated manufacturing of sensor-monitored parts. Laser Tech J. https://doi.org/10.1002/latj.201800015

Publisher's Note Springer Nature remains neutral with regard to jurisdictional claims in published maps and institutional affiliations. 